\title{
Determinants of foreign direct investment inflows: A case of the Visegrad countries
}

\author{
Aneta Bobenič Hintošová \\ Department of Management, University of Economics in Bratislava \\ Slovak Republic \\ aneta.bobenic-bintosova@euke.sk
}

\section{Michaela Bruothová}

Department of Economics, University of Economics in Bratislava

Slovak Republic

michaela.bruothova@euke.sk

\section{Zuzana Kubíková}

Department of Management, University of Economics in Bratislava

Slovak Republic

zuzana.kubikova@student.euke.sk

\section{Rastislav Ručinský}

Department of Corporate Financial Management, University of

Economics in Bratislava

Slovak Republic

rastislav.rucinsky@euke.sk

Abstract. This study identifies the determinants of foreign direct investment inflows into Visegrad countries using the country level data from the year 1989 to the year 2016. Based on correlation and regression analyses (OLS and fixed-effect model), we have identified the level of gross wages and the share of educated labour force as the most significant determinants with positive effect on FDI inflows. On the other hand, corporate income tax rate, trade openness and expenditures on research and development have been detected as the determinants with negative impact on FDI. Our study has not brought any evidence on inflation rate, unemployment rate, GDP per capita and the innovation output, as the sum of patents and trademarks, influencing FDI inflows in the case of Visegrad countries.

Keywords: foreign direct investment, inflows, location advantage, determinants, Visegrad countries.

JEL Classification: F21, M16, P33 


\section{INTRODUCTION}

Foreign direct investment (hereinafter also "FDI") and its determinants is a widely discussed topic within economic literature. It is generally believed that the advantages that FDI brings to the standard of living and prospects for economic growth of a host country largely outweigh its disadvantages (Janicki, 2004). Considerations of the reasons for investing abroad is not a new idea either. Perhaps the most widely known eclectic theory of Dunning (1981) explains that FDI is determined by three sets of advantages. Besides specific ownership and internalization advantage, a target foreign country should offer to an investor a specific location advantage. The latter may take the form of economic advantage (low prices for production factors, infrastructure, market size, geographic location, economic stability etc.), social advantage (cultural and language proximity), or political advantage (political stability, free trade, pro-investment policy).

The objective of the present paper is to identify the determinants of foreign direct investment inflows into Visegrad countries, namely, Poland, Hungary, Czech Republic and Slovak Republic, primarily focusing on the economic determinants of FDI. In many previous empirical studies the Visegrad countries have been analysed as a separate group of their own, often referred to as the "catching-up" countries (e.g., TenderaWłaszczuk, 2015). Our research has been conducted for the years of 1989-2016 using the country level data processed through correlation and regression analyses (OLS and fixed-effect model). The results indicate that from nine potential determinants of FDI five are statistically significant.

The rest of the paper is organized as follows: section 1 presents the literature review on the topic connected with the determinants of FDI inflows, specifically under the conditions of Central and Eastern European countries, section 2 introduces the dataset including summary statistics of the used variables, section 3 explains the empirical methodology, section 4 brings own empirical results and their discussion followed by the concluding remarks.

\section{LITERATURE REVIEW}

As Gauselmann (2011) stated, the Central and Eastern European countries (CEECs) were regarded as unattractive locations for foreign direct investment after the collapse of the communism. Once the transition recession was overcome and the economies started on the process of catching up with Western European levels of GDP per capita, the CEECs became prime targets for FDI. Although there is a large number of contemporary researches focusing on FDI and their determinants, the literature dealing specifically with the topic in the CEE transition economies, in particular the Visegrad countries, is rather sparse. However, Galego (2004) claims that the Visegrad countries dominate in absolute terms in FDI inflows to the region.

In the early study, Lansbury et al. (1996) attempted to identify the determinants of FDI from fourteen OECD countries to the Czech Republic and Slovakia, Hungary and Poland from 1991 to 1993, and their research results suggested that FDI was positively affected by the privatization schedule, the research base, proxied by the number of patents and the trade links.

Gauselmann (2011) analysed the determinants of FDI in five CEECs, the Czech Republic, Hungary, Poland, Romania and Slovakia, and found that investment motives are not homogeneous across various host economies. The access to localised knowledge and technology was found as an important determinant only in the Czech Republic, as well as in the Slovak Republic, although it did not appear as statistically significant in this case. Interestingly, foreign investors in Poland appear to place much less weight on this determinant. Over the whole population of the foreign investors in the CEECs, the lower cost of production factors and the market access were the most important determinants of FDI for the foreign investors.

Janicki (2004) studied the determinants of FDI in nine EU countries, specifically Bulgaria, Czech Republic, Estonia, Hungary, Poland, Slovakia, Slovenia, Romania and Ukraine. In his research, he found 
that the most important determinant of FDI was the trade openness, what was explained by the fact that trade and investments complemented one another. Moreover, market size was set to be a statistically significant positive FDI determinant, and it was expected that FDIs were greater in larger economies with well-built markets. In addition, the labour cost was found significant and positive, what was explained by the fact that cheap labour was of particular interest for the countries with high wage levels, and where firms were looking to reduce costs by relocating production to a region with resources available at a lower cost.

Bevan (2000) analysed the determinants of FDI in the CEECs, and found that FDI was determined by the host country risk and size, labour costs and distance. Altomonte (2000) concluded in his research of European firms' foreign investments in the CEECs that FDI appears to be influenced by GDP per capita, population and wage differences. Galego (2004) found out in his research of FDI flows to the CEECs that international investments are mainly determined by such characteristics as potential demand, openness to world trade and lower relative labour compensation levels. Riedl (2010) in his study of FDI to eight new EU member states, namely the Czech Republic, Estonia, Hungary, Latvia, Lithuania, Poland, Slovakia and Slovenia, found statistically significant positive impact of GDP, industrial concentration and agglomeration, while the impact of labour costs was found negative. Plikynas (2006) used an alternative and potentially innovative new methodology using neural network modelling approaches to examine the determinants of FDI in the CEECs. He estimated weights for FDI determinants nonlinearly, and proved statistically significant results for the following FDI determinants: export, market size, import, inflation, tax, unemployment and wages.

In the study of transforming countries, such as the Czech Republic, Hungary, Poland, etc., Demirhan (2008) found that market size, infrastructure and trade openness had positively affected FDI, while inflation and tax rate were indicated as significantly negative determinants of FDI. Gorbunova (2012), in the research of transition countries, such as the Czech Republic, Hungary, Poland and the Slovak Republic, suggested that FDI distribution among these countries was influenced by the specific market and institutional factors as: the cost of labour, the real exchange rate, the infrastructure, the inflow of private capital, the business registration costs, the inflation rate, the diffusion of internet users and the rigidity of employment laws.

Kowalewski (2014) in the study using firm data examined the locational trends of foreign direct investment projects undertaken by the Polish companies and proved the consistence with the evolutionary models of internationalization. Companies in the early stages of internationalization are markets and resource seeking, whereas efficiency seeking and strategic asset seeking are the companies in the advanced stages of internationalization. On the other hand, Wach (2016) showed that FDI from the EU-15 countries were allocated in the V4 countries more because of the home and host market potential measured by GDP so they can be classified as pure market-seeking horizontal FDI. Currently, investors from the mature EU15 countries, whilst allocating FDI in the V4 countries rather do not seek efficiency (as before), but the short distance is more important for them (than it used to be before the accession).

The recent study based on questionnaire sent to the investors located in the Czech Republic surprisingly showed that FDI is not influenced by any of the studied variables, namely GDP, inflation rate, current account balance, tax burden, condition of the infrastructure and condition of the human resources evaluated through unit labour costs, unit wage costs, GDP per hour worked and the rate of unemployment (Jáč, 2017).

One of the most recent huge empirical studies performed by Chanegriha (2017) covered 168 countries and considered 58 potential economic, geographic and political determinants. The general results, without specific emphasis on the particular group of countries showed that following factors had a robust relationship to FDI from an economic determinant point of view: trade openness, outgoing FDI, government spending, corporate tax rate, tertiary and secondary school enrolment. On the other hand, this study provided strong evidence against inflation being robust determinant of FDI. 
Due to ambiguity of previous findings, we have an ambition to extent the existing literature regarding determinants of foreign direct investment inflows specifically in the conditions of the Visegrad countries covering relatively long period including the latest available data.

\section{METHODOLOGY}

As a source of the data, the FDI/TNC database of UNCTAD, the databases of World Development Indicators and the databases of Eurostat are used. The data are reported on a country level from 1989 to 2016, which was the most recent year, as FDI inflow is processed into the annual reports approximately 18 months after the end of the respective period. We collected the aggregate data of the Visegrad countriesPoland, Hungary, the Czech Republic and the Slovak Republic. The dataset contains 155 missing values due to unavailability of the data, which represents $11.96 \%$ of the total data values.

Since the key dependent variable of our framework is represented by foreign direct investment inflows, we provide detailed comparison of FDI inflows within the Visegrad countries based on the data reported by UNCTAD. This organisation regularly collects published and unpublished national official FDI data directly from central banks, statistical offices or national authorities on an aggregated and disaggregated basis for its FDI/TNC database. The data on FDI flows are constructed on a net basis (capital transactions' credits less debits between direct investors and their foreign affiliates). FDI flows with a negative sign indicate that at least one of the three components of FDI (equity capital, reinvested earnings or intracompany loans) is negative and not offset by positive amounts of the remaining components.

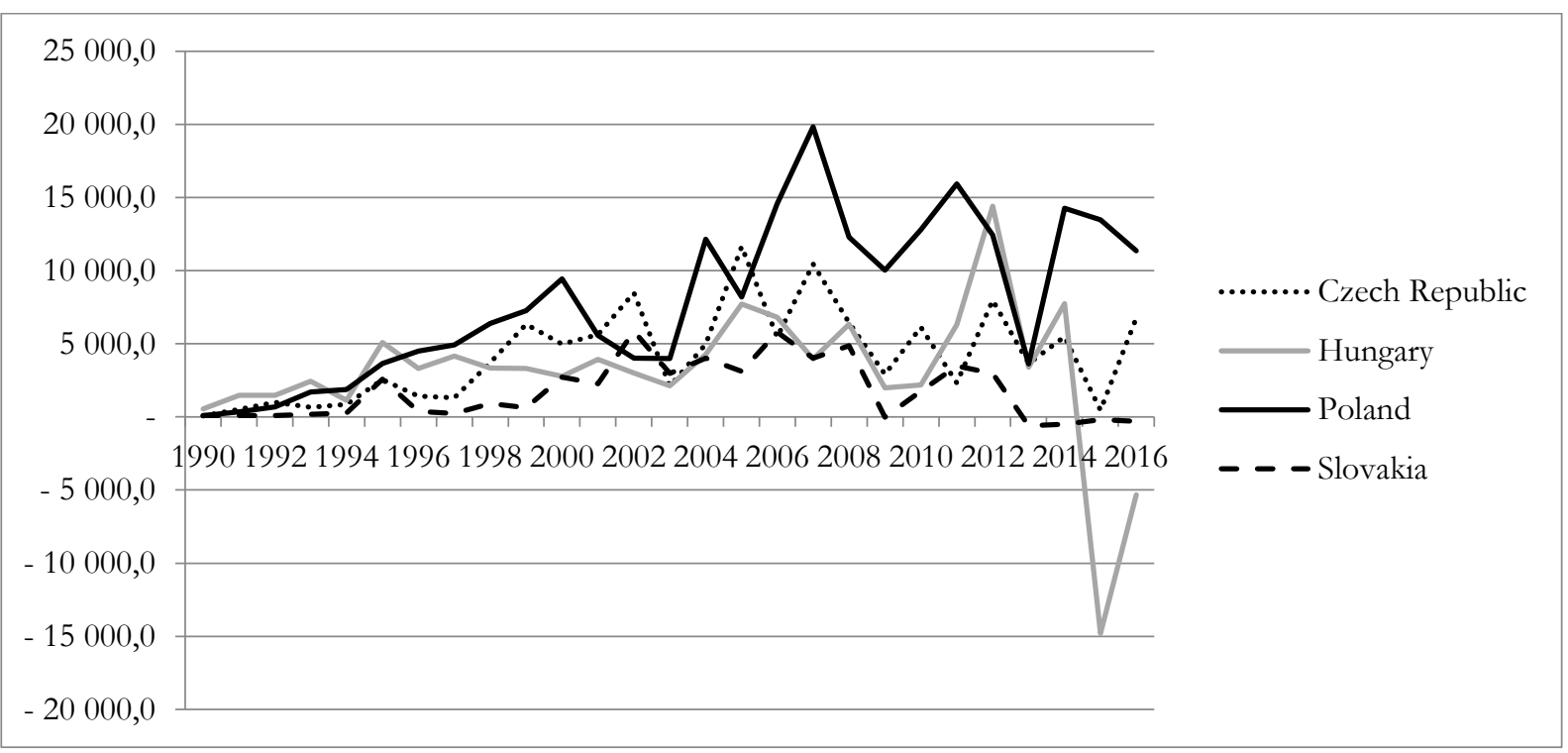

Figure 1. Evolution of FDI inflows in V4 countries in millions of dollars Source: FDI/TNC database of UNCTAD

As Figure 1 indicates, FDI inflows in the case of all the V4 countries had, in general, increasing tendency from the beginning of the observed period and achieved its peak around 2007-2008 followed by decrease in the context of global economic crisis. According to Simionescu (2017), the V4 states attracted a significant amount of FDI before the crisis due to favourable economic environment for investors and an openness to international capital mobility. From 2010, we observe divergent evolution of FDI flowing into the Visegrad countries with negative values in the recent years valid for Slovakia and Hungary. Based on 
this evolution we can assume that different potential determinants of FDI played different role in the particular countries.

The potential determinants of FDI inflow are selected in accordance with the previous empirical findings of researchers described above, and the variables in the models are constructed in the same way for all studied countries, in order to provide comparable results. The possible determinants of FDI inflow are the following: market size, labour costs and quality of labour, trade openness, economic stability, innovation and taxation. Input data for construction of independent variables are derived from Eurostat and the databases of World Development Indicators.

The market size is measured by gross domestic product per capita, which can be considered as comparable variable among countries, because it is divided by the number of inhabitants in a country. The same variable for measuring market size as the determinant of FDI was used for example by Birsan (2009), Demirhan (2008), Culahovic (2008), Galego (2004), Sánchez-Martín (2014), Vlahinić-Dizdarević (2005), Plikynas (2006), Sun (2002). In this paper, GDP is the sum of gross value added by all resident producers in the country, plus any product taxes and minus any subsidies not included in the value of the products. It is calculated without making deductions for depreciation of fabricated assets, or for depletion and degradation of natural resources. GDP per capita is gross domestic product divided by midyear population (in the paper denoted as GDP).

The costs of labour $(W)$ are represented by average gross wages of employees (similarly measured in the study by Demirhan, 2008, Culahovic, 2008, Plikynas, 2006, Janicki, 2004, Galego, 2004, Sun, 2002, Zheng, 2009), while the labour quality (EDU) is captured in the share of total labour force, who attained or completed at least secondary education (as measured by Gorbunova, 2012, Sánchez-Martín, 2014).

The trade openness $(T O)$ of a country is measured by the sum of export and import, divided by GDP. The same variable was used in the research of FDI determinants by Culahovic (2008), Sánchez-Martín (2014), or Wei (2007). Exports of goods and services comprise all transactions between residents of a country and the rest of the world, involving a change of ownership from residents to non-residents of general merchandise, net exports of goods, non-monetary gold and services. Similarly, imports of goods and services involve a change of ownership from non-residents to residents of general merchandise, nonmonetary gold and services. The both variables, as well as GDP are measured in the same currency.

The economic stability is represented by the unemployment rate (as used in the research of FDI determinants by Wei, 2007), and the inflation rate (e.g. by Demirhan, 2008, Vlahinić-Dizdarević, 2005, Wei, 2007, Zheng, 2009), where the inverse relation between unemployment, or inflation and economic stability is expected, because economic stability is supposed to decline, when there is a rising unemployment and inflation in a country (Culahovic, 2008). Unemployment rate (UN) refers to the percentage of the labour force that is without work, but available for and seeking employment. Inflation (INF) is measured by the harmonised index of consumer prices compared to year 2015 (HICP is 100 \% for each country in 2015), and reflects the average change over the time in the prices paid by households for a specific, regularly updated basket of consumer goods and services.

The innovation is measured by two variables. The first one represents the innovation output $(I O)$, which is the sum of patent applications filed through the Patent Cooperation Treaty procedure or with a national patent office, and trademark applications to register a trademark with a national or regional Intellectual Property Office. The innovation output is similarly measured for example by Sun (2002), or Boermans (2011) in the research of FDI determinants in China. The second one is the innovation input, which is represented by expenditures on research and development $(R \Theta D)$, measured as current and capital expenditures on the creative work undertaken systematically to increase knowledge, including knowledge of humanity, culture and society, and the use of knowledge for new applications, as a percentage of GDP. 
Similarly, Pradhan (2011) or Sun (2002) used the same variable for measuring the innovation input as the determinant of FDI in their research.

The taxation $(T A X)$ is measured by the level of corporate income tax rate in a country, similarly as measured by Eicher (2012) or Plikynas (2006) in their research of FDI determinants.

Table 1 presents the summary statistic, namely mean, median, standard deviation, skewness and excess kurtosis, of all used variables, which are defined above. The inflow of FDI is on average 4,284 million of USD in the Visegrad countries. The average GDP in these countries is 7,992 euro per inhabitant. The average sum of export plus import divided by GDP in these countries is 1.21. The employees earn on average 1,112 USD per month brutto. On average, $68.96 \%$ of the labour force in the Visegrad countries completed at least secondary education. The expenditure on R\&D in these countries represents on average $0.92 \%$ of GDP and the average innovation output is 15,642 trademark, or patent applications. The average corporate income tax rate is $26.69 \%$ in these countries. The average inflation rate is $78.30 \%$, and the average unemployment rate is $10.36 \%$.

The relatively high differences between mean and median in the case of variables FDI, GDP, $W$ and $I O$ indicate possible extreme values in the distributions. Based on the values of skewness, the variables FDI, and EDU seem highly skewed, the variables $W, I O, R \Theta D, T A X$ and $I N F$ are moderately skewed, and the other variables are approximately symmetric. The distributions of the variables FDI, EDU and R\&D seem leptokurtic, while the other variables seem platykurtic, based on the values of excess kurtosis.

Table 1

Summary statistics

\begin{tabular}{|c|c|c|c|c|c|}
\hline Variable & Mean & Median & Std. Dev. & Skewness & Ex. Kurtosis \\
\hline FDI & 4284 & 3323 & 4872 & 0.64 & 3.26 \\
\hline GDP & 7992 & 7200 & 4268 & 0.60 & -0.45 \\
\hline TO & 1.21 & 1.26 & 0.39 & -0.17 & -0.96 \\
\hline W & 1112 & 43 & 4857 & 4.31 & 16.62 \\
\hline TAX & 26.69 & 20.50 & 9.49 & 0.68 & -1.08 \\
\hline EDU & 68.96 & 70.20 & 9.33 & -1.31 & 2.41 \\
\hline INF & 78.30 & 80.70 & 18.02 & -0.60 & -0.54 \\
\hline UN & 10.36 & 10.05 & 4.16 & 0.48 & -0.38 \\
\hline R\&D & 0.92 & 0.89 & 0.36 & 1.00 & 0.78 \\
\hline IO & 15641 & 13198 & 7781 & 0.48 & -0.72 \\
\hline
\end{tabular}

Source: own processing of the data

Table 2 introduces the correlation matrix of all used variables. The pairs of two variables with the high correlation were excluded from the empirical models to avoid serious multicollinearity. We considered a correlation coefficient of 0.7 or above as a high value, as it was stated in paper by Sun (2002). To avoid multicollinearity problem in the models, we analyse the VIF values in every model.

Based on the correlation coefficients, the positive effect of the variables IO, INF and $U N$, while the negative effect of the variables GDP, TO, $W, E D U, R \otimes D$ and $T A X$ on FDI inflow are expected in the following models. 
Correlation matrix

\begin{tabular}{|c|c|c|c|c|c|c|c|c|c|}
\hline Variable & $G D P$ & $T O$ & $W$ & $E D U$ & IO & $R \& D$ & $T A X$ & $I N F$ & $U N$ \\
\hline$F D I$ & $\begin{array}{c}-0.1675^{* * *} \\
(0.0080)\end{array}$ & $\begin{array}{l}-0.4940 \\
(0.1291)\end{array}$ & $\begin{array}{c}-0.0837 * * * \\
(0.0008)\end{array}$ & $\begin{array}{c}-0.0125^{* * *} \\
(0.0020)\end{array}$ & $\begin{array}{c}0.4828^{* * *} \\
(0.0000)\end{array}$ & $\begin{array}{l}-0.2100 \\
(0.7743)\end{array}$ & $\begin{array}{c}-0.0785^{* * *} \\
(0.0000)\end{array}$ & $\begin{array}{c}0.0375 \\
(0.1827)\end{array}$ & $\begin{array}{c}0.0849 \\
(0.7049)\end{array}$ \\
\hline$G D P$ & 1 & $\begin{array}{c}0.4940 * * * \\
(0.0000)\end{array}$ & $\begin{array}{c}0.3386^{* * *} \\
(0.0000)\end{array}$ & $\begin{array}{c}-0.0559 * * * \\
(0.0004)\end{array}$ & $\begin{array}{l}-0.5372^{*} \\
(0.0308)\end{array}$ & $\begin{array}{c}0.6225^{* * *} \\
(0.0000)\end{array}$ & $\begin{array}{c}-0.5281^{* * *} \\
(0.0000)\end{array}$ & $\begin{array}{c}0.8354^{* * *} \\
(0.0000)\end{array}$ & $\begin{array}{l}-0.3778^{*} \\
(0.0304)\end{array}$ \\
\hline$T O$ & & 1 & $\begin{array}{c}0.1337 \\
(0.3337)\end{array}$ & $\begin{array}{c}0.0532 \\
(0.1960)\end{array}$ & $\begin{array}{c}-0.9117 * * * \\
(0.0000)\end{array}$ & $\begin{array}{c}0.3376^{* *} \\
(0.0173)\end{array}$ & $\begin{array}{c}-0.4155^{* * *} \\
(0.0000)\end{array}$ & $\begin{array}{c}0.3583^{* * *} \\
(0.0045)\end{array}$ & $\begin{array}{l}-0.1273 \\
(0.4984)\end{array}$ \\
\hline$W$ & & & 1 & $\begin{array}{c}-0.4590^{* *} \\
(0.0484)\end{array}$ & $\begin{array}{c}-0.1565^{* * *} \\
(0.0002)\end{array}$ & $\begin{array}{c}0.2900 \\
(0.3590)\end{array}$ & $\begin{array}{c}-0.1251^{* * *} \\
(0.0000)\end{array}$ & $\begin{array}{c}0.2832^{* * *} \\
(0.0000)\end{array}$ & $\begin{array}{l}-0.1566 \\
(0.7704)\end{array}$ \\
\hline$E D U$ & & & & 1 & $\begin{array}{c}0.0374 * * \\
(0.0444)\end{array}$ & $\begin{array}{l}-0.1652 \\
(0.8186)\end{array}$ & $\begin{array}{c}0.2191 * * \\
(0.0395)\end{array}$ & $\begin{array}{c}-0.0105^{* *} \\
(0.0223)\end{array}$ & $\begin{array}{c}0.2164 \\
(0.8411)\end{array}$ \\
\hline$I O$ & & & & & 1 & $\begin{array}{l}-0.2925 \\
(0.3549)\end{array}$ & $\begin{array}{c}0.4009 \\
(0.4059)\end{array}$ & $\begin{array}{c}-0.3780^{*} \\
(0.0586)\end{array}$ & $\begin{array}{c}0.1211 \\
(0.1374)\end{array}$ \\
\hline$R \& D$ & & & & & & 1 & $\begin{array}{l}-0.1325 \\
(0.7532)\end{array}$ & $\begin{array}{c}0.4107 * * * \\
(0.0063)\end{array}$ & $\begin{array}{c}-0.6039 * * * \\
(0.0000)\end{array}$ \\
\hline$T A X$ & & & & & & & 1 & $\begin{array}{c}-0.5141 * * * \\
(0.0000) \\
\end{array}$ & $\begin{array}{c}0.2054 \\
(0.3651)\end{array}$ \\
\hline$I N F$ & & & & & & & & 1 & $\begin{array}{l}-0.0865 \\
(0.8341)\end{array}$ \\
\hline$U N$ & & & & & & & & & 1 \\
\hline
\end{tabular}

Source: own processing of the data. $*$ indicates significance level at 0.10 level, $* *$ indicates significance level at 0.05 level, *** indicates significance level at 0.01 level.

To study the effect of the possible determinants on the FDI inflow, four following models are constructed:

$$
\begin{aligned}
& \operatorname{lnFDI} I_{c t}=\alpha+\beta_{1} \ln G D P_{c(t-1)}+\beta_{2} \operatorname{lnI} O_{c(t-1)}+\beta_{3} T A X_{c(t-1)}+\beta_{4} E D U_{c(t-1)}+\varepsilon_{c t} \\
& \operatorname{lnFDI} c t=\alpha+\beta_{1} T O_{c(t-1)}+\beta_{2} E D U_{c(t-1)}+\beta_{3} \operatorname{lnIO} O_{c(t-1)}+\beta_{4} T A X_{c(t-1)}+\varepsilon_{c t} \\
& \operatorname{lnFDI} I_{c t}=\alpha+\beta_{1} T O_{c(t-1)}+\beta_{2} \ln W_{c(t-1)}+\beta_{3} E D U_{c(t-1)}+\beta_{4} U N_{c(t-1)}+\varepsilon_{c t} \\
& \operatorname{lnFDI} I_{c t}=\alpha+\beta_{1} U N_{c(t-1)}+\beta_{2} I N F_{c(t-1)}+\beta_{3} R \& D_{c(t-1)}+\beta_{4} T O_{c(t-1)}+\varepsilon_{c t}
\end{aligned}
$$

In the models, $\ln F D I$ is the logarithm of FDI inflow, $\ln G D P$ is the logarithm of gross domestic product per capita, $\ln I O$ represents the innovation output, while R\&D the innovation input, $T A X$ is the corporate tax rate, EDU represent the quality of labour, $T O$ is the trade openness, $\ln W$ is the logarithm of wages, $U N$ represents the unemployment rate and INF the inflation rate. $a$ denotes the constant in the models, $\beta s$ are the coefficients to be estimated by regression analysis and $\varepsilon$ is the error term. The country and time subscripts are denoted by $c$ and $t$.

The logarithms of the variables are used, when the values are in absolute numbers, similarly as in the research of FDI determinants conducted by Demirhan (2008), Sun (2002) or Gorbunova (2012). Based on the values of Dickey-Fuller test the stationarity of the data was not excluded.

Our research is based on regression analysis (OLS and fixed-effect model) as the standard and the prevailing methodology regarding identification of the determinants of FDI. However, other approaches that have not yet found widespread application in the analysis of the determinants of FDI can be found in 
the existing literature. We can mention neural network modelling used by Plikynas (2006) or Extreme Bound Analysis applied by Chanegriha (2017).

\section{EMPIRICAL RESULTS AND DISCUSSION}

The empirical results obtained from the fixed-effect estimation of a model (1) are shown in the Table 3. The reported numbers for each variable are beta coefficients and their standard errors, t-statistics, $\mathrm{p}$ values and collinearity statistics (variance inflation factor VIF). All values of VIF lower than 5 do not indicate multicollinearity problem in the model. Based on the p-values, only the variable TAX is statistically significant at the level of $5 \%$. The variables $\ln$ GDP, $\ln I O$ and EDU seem not statistically significant determinants of FDI inflow in this model. We can interpret the beta coefficients of the variables as one percent change in the income tax rate leading to $6 \%$ decrease of FDI inflow.

The value of the coefficient of determination indicates that this model can explain $34 \%$ of the variation in the dependent variable. The low p-value of F-statistic confirms the significance of the overall regression model. The Ramsey RESET test statistic with the p-value higher than 0.05 does not lead to the rejection of the null hypothesis, and it can be concluded that the model does not suffer from misspecification. The White's test for heteroscedasticity with a high p-value does not show a heteroscedasticity problem. Reported Durbin-Watson statistic does not indicate serial autocorrelation problem in the model. The low p-value of joint significance of differing group means leads to the rejection of the null hypothesis that the pooled OLS model is adequate. Hence, the fixed-effect model estimation was used. However, the test for normality of residuals with the Chi-squared statistic equals 35.92 and the p-value 0.0000 leads to the rejection of the null hypothesis that error is normally distributed. Therefore, the p-values should be assessed more strictly.

Table 3

Fixed effect model (1) estimation

\begin{tabular}{|c|c|c|c|c|c|}
\hline Model (1) & Coefficient & Std. Error & t-ratio & p-value & VIF \\
\hline Const & $13,62 *$ & 7,903 & 1,72 & 0,09 & 0,25 \\
\hline $\ln$ GDP & $-0,56$ & 0,490 & $-1,15$ & 0,95 & 1.238 \\
\hline $\ln I O$ & 0,03 & 0,403 & 0,06 & 0,03 & 2.249 \\
\hline TAX & $-0,06 * *$ & 0,027 & $-2,27$ & 0,27 & 1.135 \\
\hline EDU & 0,01 & 0,012 & 1,10 & 0.8317 \\
\hline Sum squared residuals & 50.498 & S.E. of regression & 0.1452 \\
\hline LSDV R-squared & 0.34 & Within R-squared & 0.0001 \\
\hline F(7, 73) & 5.40 & with p-value & 0.9614 \\
\hline White's test & 6.19 & with p-value & 0.6226 \\
\hline RESET test & 0.48 & with p-value & 0.0948 \\
\hline Joint significance & 2.20 & with p-value & \\
\hline Durbin-Watson & 1.76 & with p-value & \\
\hline Chi-squared statistics & 35.92 &
\end{tabular}

Source: own processing of the data. * indicates significance level at 0.10 level, ** indicates significance level at 0.05 level, *** indicates significance level at 0.01 level.

Similarly, Table 4 shows the empirical results of the pooled OLS estimation of a model (2). The reported numbers for each variable are beta coefficients and their standard errors, $\mathrm{t}$-statistics, $\mathrm{p}$-values and collinearity statistics. Based on the p-values, the variable TAX is statistically significant at the level of $1 \%$, and TO is statistically significant at the level of $10 \%$. The variables EDU and $\ln I O$ do not seem to be 
statistically significant determinant of FDI inflow in this model. Based on the empirical results, one percent change in the trade openness leads to $57 \%$ decrease of FDI inflow; and one percent change in the tax rate leads to $6 \%$ decrease of FDI inflow.

The values of VIF do not exceed 5, hence we do not suspect multicollinearity problem in the model. The value of the coefficient of determination indicates that this model can explain $31 \%$ of the variation in the dependent variable. The overall significance and appropriate specification of the model (2) are confirmed by the F-statistic and the Ramsey RESET test. The White's test for heteroscedasticity does not lead to suspicion of a heteroscedasticity problem in the model, and the Durbin-Watson statistic does not indicate serial autocorrelation problem. The high p-values of joint significance of differing group means does not lead to the rejection of the null hypothesis that the pooled OLS model is adequate. However, as in the previous model (1), the test for normality of residuals with the Chi-squared statistic equals 29.72 and the pvalue 0.0000 leads to the rejection of the null hypothesis that error is normally distributed.

Table 4

Pooled OLS model (2) estimation

\begin{tabular}{|c|c|c|c|c|c|}
\hline Model (2) & Coefficient & Std. Error & t-ratio & p-value & VIF \\
\hline Const & $5.94^{*}$ & 3.12 & 1.90 & 0.06 & 0.06 \\
\hline TO & $-0.85 *$ & 0.44 & -1.94 & 0.33 & 3.678 \\
\hline EDU & 0.01 & 0.01 & 0.98 & 0.15 & 2.991 \\
\hline lnIO & 0.43 & 0.29 & 1.47 & 0.00 & 1.422 \\
\hline TAX & $-0.06 * * *$ & 0.01 & -4.48 & 0.8312 \\
\hline Sum squared residuals & 52.52 & S.E. of regression & 0.2786 \\
\hline R-squared & 0.31 & Adjusted R-squared & 0.0000 \\
\hline F(4, 76) & 8.72 & with p-value & 0.9824 \\
\hline White's test & 5.22 & with p-value & 0.1055 \\
\hline RESET test & 2.32 & with p-value & 0.7018 \\
\hline Joint significance test & 0.61 & with p-value & \\
\hline Durbin-Watson & 1.84 & with p-value & \\
\hline Chi-squared statistics & 29.72 & \\
\hline
\end{tabular}

Source: own processing of the data. * indicates significance level at 0.10 level, $* *$ indicates significance level at 0.05 level, *** indicates significance level at 0.01 level.

Table 5 reports the empirical results of the pooled OLS estimation of a model (3). Based on the pvalues, the variables TO and $\ln \mathrm{W}$ are statistically significant determinants of FDI inflow at the level of $1 \%$, and EDU is statistically significant at the level of $10 \%$. The variable UN does not seem to be statistically significant in this model. Based on the empirical results, one unit increase in the trade openness leads to approximately $52 \%$ decrease of FDI inflow; increase of wages by $10 \%$ is followed by $28 \%$ increase of FDI inflow; and one percent increase in the share of educated labour force causes $2 \%$ increase of FDI inflow.

Based on the values of VIF, we do not suspect multicollinearity problem in the model (3), and the Durbin-Watson statistic does not indicate serial autocorrelation problem either. The value of the coefficient of determination reports that $25 \%$ of the variation in the dependent variable can be explained by this model. The overall significance and appropriate specification of the model (3) are confirmed by the F-statistic and the Ramsey RESET test. The White's test for heteroscedasticity does not lead to suspicion of a heteroscedasticity problem in the model. The p-values higher than 0.05 of joint significance of differing group means does not lead to the rejection of the null hypothesis that the pooled OLS model is adequate. 
However, as in the previous two models, the test for the normality of residuals with the Chi-squared statistic equals 17.68 and the p-value 0.0000 leads to the rejection of the normality of residuals.

Table 5

Pooled OLS model (3) estimation

\begin{tabular}{|c|c|c|c|c|c|}
\hline Model (3) & Coefficient & Std. Error & t-ratio & p-value & VIF \\
\hline Const & $6.49^{* * *}$ & 0.99 & 6.53 & 0.00 & 0.01 \\
\hline TO & $-0.74^{* * *}$ & 0.27 & -2.68 & 0.00 & 1.027 \\
\hline $\ln W$ & $0.29 * * *$ & 0.08 & 3.54 & 0.06 & 1.218 \\
\hline EDU & $0.02 *$ & 0.01 & 1.92 & 0.39 & 1.146 \\
\hline UN & 0.02 & 0.03 & 0.86 & 0.8736 \\
\hline Sum squared residuals & 54.19 & S.E. of regression & 0.2072 \\
\hline R-squared & 0.25 & Adjusted R-squared & 0.0004 \\
\hline F(4, 71) & 5.90 & with p-value & 0.8289 \\
\hline White's test & 9.03 & with p-value & 0.0668 \\
\hline RESET test & 2.82 & with p-value & 0.1326 \\
\hline Joint significance test & 1.93 & with p-value & \\
\hline Durbin-Watson & 1.76 & with p-value & \\
\hline Chi-squared statistic & 17.68 & & \\
\hline
\end{tabular}

Source: own processing of the data. * indicates significance level at 0.10 level, ** indicates significance level at 0.05 level, *** indicates significance level at 0.01 level.

Analogously, Table 6 shows the empirical results of the fixed-effect estimation of a model (4). Based on the p-values, the variable R\&D is statistically significant at the level of $1 \%$. Hence, one percent increase in the innovation expenditures leads to $82 \%$ decrease of FDI inflow. The variables UN, INF and TO do not seem to be statistically significant determinant of FDI inflow in this model.

Table 6

Fixed-effect model (4) estimation

\begin{tabular}{|c|c|c|c|c|c|}
\hline Model (4) & Coefficient & Std. Error & t-ratio & p-value & VIF \\
\hline Const & $7.53 * * *$ & 0.77 & 9.75 & 0.00 & 0.19 \\
\hline UN & 0.05 & 0.03 & 1.32 & 0.65 & 1.621 \\
\hline INF & 0.01 & 0.01 & 0.45 & 0.00 & 1.854 \\
\hline R\&D & $-1.71 * * *$ & 0.52 & -3.27 & 0.34 & 1.168 \\
\hline TO & 1.14 & 1.18 & 0.96 & 0.8197 \\
\hline Sum squared residuals & 45.02 & S.E. of regression & 0.1812 \\
\hline LSDV R-squared & 0.39 & Within R-squared & 0.0000 \\
\hline F(7, 67) & 6.03 & P-value(F) & 0.5864 \\
\hline White's test & 12.25 & with p-value & 0.2518 \\
\hline RESET test & 1.41 & with p-value & 0.0004 \\
\hline Joint significance test & 6.97 & with p-value & \\
\hline Durbin-Watson & 1.97 & with p-value & \\
\hline Chi-squared statistic & 36.56 &
\end{tabular}

Source: own processing of the data. * indicates significance level at 0.10 level, $* *$ indicates significance level at 0.05 level, $* * *$ indicates significance level at 0.01 level. 
The values of VIF do not lead to the suspicion of multicollinearity problem in the model. The value of the coefficient of determination indicates that this model can explain 39\% of the variation in the dependent variable. The overall significance and appropriate specification of the model (4) are confirmed by the F-statistic and the Ramsey RESET test. The White's test for heteroscedasticity does not lead to the suspicion of a heteroscedasticity problem in the model, and the Durbin-Watson statistic does not indicate serial autocorrelation problem. The low p-value of joint significance F-test is in favour of the use of the fixed-effect alternative, in comparison to the pooled OLS estimation, thus the fixed-effect estimations are reported.

The results of the four models bring interesting findings. One of the frequently studied efficiency seeking variables, namely the tax rate has highly significant and negative effect on FDI. Thus, higher tax rates, as one aspect of company's costs, discourage foreign investors. This finding is in line with previous research by Demirhan (2008). Similarly, Chanegriha (2017) concluded that the business taxation is an important factor for maintaining a thriving business environment; the role of the government is to set up an appropriate policy.

Interestingly, based on the results the foreign investors are attracted by labour quality, even if the labour costs represented by gross wages are higher in a host country. As Gorbunova (2012) states, relatively higher labour costs are often associated with the better infrastructures and stable macroeconomic context, so that foreign investor prefers to invest in the countries with these characteristics. The positive effect of higher wages on FDI inflows can be also explained by the sectoral orientation of investments. The investors oriented especially at more knowledge intensive sectors can link higher wages with higher quality of the human force. Thus, we can agree with Chanegriha (2017) that the education at secondary and tertiary levels suggests the need for the human capital to be promoted and the skills and labour productivity to be developed more broadly. Deeper study of the relationship between sectoral distribution of FDI and human capital aspects can be a subject of a future research in this field.

The negative association between the innovation input represented by expenditures on research and development and FDI is in line with the study of Gauselmann (2011) who suggested that the CEECs might not be as detached from the Western technological development as traditionally believed, and might be able to offer new technical knowledge specific to the region. The price of the access to technology, however, seems negatively influence FDI inflow. According to these results, the investors in the V4 countries are rather not technology-seeking ones.

In the case of trade openness, the results suggest that FDI flows are substituted, rather than complemented by export and import in a host country, which is an opposite to findings by Janicki (2004). Higher trade openness generally connected with the effort of governments to maintain economies open to international trade, fostering competition and innovation (Chanegriha, 2017) can on the other hand discourage efficiency seeking investors that can be the case of the V4 countries. Our slightly controversial results at the same time create a space for deeper analysis of the types of investments and special characteristics of investors.

Even though the market size, proxied by GDP per capita and the economic stability that stands for the inverse ratio of unemployment and inflation rate in our research, is generally expected to influence the volume of FDI to a host country, the opposite is found true for the Visegrad countries. In compliance with the findings by Jác (2017), the basic macroeconomic indicators are not considered as statistically significant determinants of foreign direct investment in our study. It may be caused by the fact that these countries try to attract a foreign investor with other governmental instruments, such as an investment aid in the form of tax reliefs or the other investment incentives. The confirmation of the positive and statistically significant relationship between provided fiscal investment aid and foreign direct investment inflows in the conditions 
of the Slovak republic can be found in the study by Bobenič Hintošová (2017). Extension of this study to the conditions of other countries is on agenda of a future research.

\section{CONCLUSION}

The objective of the present paper was to identify the determinants of foreign direct investment inflows into the Visegrad countries, primarily focusing on selected nine potential determinants of FDI. The limited number of potential determinants as well as the application of traditional methodology based on regression analysis can be considered as the most significant limitations of our research. On the other hand, the research covers relatively long period, from 1989 to 2016, including the latest available data.

To sum up, our findings confirmed some of the results presented by other studies performed in the conditions of the similar countries; however, some of our findings are rather controversial. In our study, we have identified the level of gross wages and the share of labour force with achieved at least secondary education, as the most significant determinants with the positive effect on FDI inflows. This finding can indicate that investors in the V4 countries can be oriented more at the knowledge intensive sectors that are linked with higher wages and higher qualification of the human force. However, more detailed research on the sectoral distribution of FDI would be desirable to verify this presumption.

On the other hand, corporate income tax rate, trade openness and expenditures on research and development have been detected as the determinants with negative impact on FDI. Our study has not brought any evidence on GDP per capita, inflation rate, unemployment rate and the innovation output, influencing FDI inflows in the case of the Visegrad countries. We can assume that the V4 countries put emphasis on the other governmental instruments, such as the investment aid in the form of tax reliefs, or the other investment incentives, in the process of FDI attraction. This agenda, based on the inclusion of more variables as potential determinants of FDI, can form the direction of the future research.

\section{ACKNOWLEDGEMENT}

The paper presents partial results of the research project VEGA No. 1/0842/17 "The causality links between foreign direct investments and firms' performance" in the frame of the granting program of the Scientific Grant Agency of Ministry of Education, Science, Research and Sport of the Slovak Republic and Slovak Academy of Sciences.

\section{REFERENCES}

Altomonte, C. (2000). Economic Determinants and Institutional Frameworks: FDI in Economies in Transition. Transnational Corporations, 9(2), 75-106.

Bevan, A., \& Estrin, S. (2000). The Determinants of Foreign Direct Investment in Transition Economies. London: Centre for New and Emerging Markets, London Business School.

Birsan, M., \& Buiga, A. (2009). FDI determinants: Case of Romania. Transition Studies Review, 15(4), 726-736. doi: http://dx.doi.org/10.1007/s11300-008-0033-2

Bobenič Hintošová, A., \& Ručinský, R. (2017). Foreign direct investments and forms of investment aid. ISCOBEMM 2017: proceedings of the 2nd international scientific conference of business economics, management and marketing. Brno: Masaryk University, 29-35.

Boermans, M.A., Roelfsema, H., \& Zhang, Y. (2011). Regional determinants of FDI in China: a factor-based approach. Journal of Chinese Economic and Business Studies, 9(1), 23-42. doi: 10.1080/14765284.2011.542884

Chanegriha, M., Stewart, C., \& Tsoukis, C. (2017). Identifying the robust economic, geographical and political determinants of FDI: an Extreme Bounds Analysis. Empirical Economics, 52(2), 759-776. doi: https://doi.org/10.1007/s00181-016-1097-1 
Culahovic, B., Mehic, E., \& Agic, E. (2008). Location Determinants of Mne Activity in the Manufacturing Industry in South East Europe Countries. Conference Proceedings: International Conference of the Faculty of Economics Sarajevo (ICES). Sarajevo: University of Sarajevo, 1-18.

Demirhan, E., \& Masca, M. (2008). Determinants of foreign direct investment flows to developing countries: a crosssectional analysis. Prague Economic Papers, 17(4), 356-369. doi: https://doi.org/10.18267/j.pep.337

Dunning, J. (1981). International Production and the Multinational Enterprise. London: Allen \& Unwin.

Eicher, T.S., Helfman, L., \& Lenkoski, A. (2012). Robust FDI determinants: bayesian model averaging in the presence of selection bias. Journal of Macroeconomics, 34(3), 637-651. doi: https://doi.org/10.1016/j.jmacro.2012.01.010

Eurostat, European Commission. Retrieved October 12, 2017 from http:/ /ec.europa.eu/eurostat

FDI Interactive Database, UNCTAD. Retrieved October 18, 2017 from: http://unctad.org/en/Pages/DIAE/FDI\%20Statistics/Interactive-database.aspx.

Galego, A., Vieira, C., \& Vieira, I. (2004). The CEEC as FDI Attractors. A Menace to the EU Periphery?. Emerging Markets Finance and Trade, 40(5), 74-91. doi: 10.1080/1540496X.2004.11052585

Gauselmann, A., Knell, M., \& Stephan, J. (2011). What drives FDI in Central - Eastern Europe? Evidence from the IWH - FDI - Micro database. Post-Communist Economies, 23(3), 343-357. doi: 10.1080/1540496X.2004.11052585

Gorbunova, Y., Infante, D., \& Smirnova, J. (2012). New evidence on FDI determinants: an appraisal over the transition period. Prague Economic Papers, 21(2), 129-149. doi: https://doi.org/10.18267/j.pep.415

Jáč, I., \& Vondráčková, M. (2017). The perception of selected aspects of investment attractiveness by businesses making investments in the Czech Republic. E\&M Economics and Management, 20(3), 118 - 132. doi: dx.doi.org/10.15240/tul/001/2017-3-008

Janicki, A., \& Wunnava, P.V. (2004). Determinants of foreign direct investment: empirical evidence from EU accession candidates. Applied Economics, 36(5), 505-509. doi: https://doi.org/10.1080/00036840410001682214

Kowalewski, O., \& Radło, M.J. (2014). Determinants of foreign direct investment and entry modes of Polish multinational enterprises: A new perspective on internationalization. Communist and Post-Communist Studies, 47(34), 365-374. doi: https://doi.org/10.1016/j.postcomstud.2014.10.003

Lansbury, M., Pain, N., \& Smidkova, K. (1996). Foreign Direct Investment in Central Europe Since 1990: An Econometric Study. National Institute Economic Review, 156(1), 104-113.

Plikynas, D., \& Akbar, Y. H. (2006). Neural Network Approaches to Estimating FDI Flows. Evidence from Central and Eastern Europe. Eastern European Economics, 44(3), 29-59. doi: 10.2753/EEE0012-8755440302

Pradhan, R.P. (2011). Dynamic panel data model and FDI determinants in India. The IUP Journal of Financial Economics, 10(1), 33-41.

Riedl, A. (2010). Location factors of FDI and the growing services economy. Economics of Transition, 18(4), 741-761. doi: https://doi.org/10.1111/j.1468-0351.2010.00391.x

Sánchez-Martín, M.E., Arce, R., \& Escribano, G. (2014). Do changes in the rules of the game affect FDI flows in Latin America? A look at the macroeconomic, institutional and regional integration determinants of FDI. European Journal of Political Economy, 34(1), 279-299.

Simionescu, M., Lazányi, K., Sopková, G., Dobeš, K., \& Balcerzak, A.P. (2017). Determinants of economic growth in V4 countries and Romania. Journal of Competitiveness, 9(1), 103-116. doi: 10.7441/joc.2017.01.07

Sun, Q., Tong, W., \& Yu, Q. (2002). Determinants of foreign direct investment across China. Journal of International Money and Finance, 21(1), 79-113. doi: https://doi.org/10.1016/S0261-5606(01)00032-8

Tendera-Właszczuk, H., \& Szymański, M. (2015). Implementation of the welfare state in the Visegrád countries. Economics \& Sociology. 8(2), 126-142. doi: 10.14254/2071- 789X.2015/8-2/10

Vlahinić-Dizdarević, N., \& Biljan-August, M. (2005). FDI performance and determinants in southeast European countries: evidence from cross-country data. Sixth International Conference on Enterprise in Transition. Split, Croatia: University of Split, Faculty of Economics, 1363-1377.

Wach, K., \& Wojciechowski, L. (2016). Determinants of inward FDI into Visegrad countries: empirical evidence based on panel data for the years 2000 - 2012. Economics and Business Review, 2(1), 34-52. doi: 10.18559/ebr.2016.1.3

Wei, S.Z.C., \& Zhu, Z. (2007). A revisit to the outward FDI determinants: further evidence from count panel data models with fixed effects. Applied Economics Letters, 14(11), 809-812. doi: 10.1080/13504850600689923 
World Development Indicators (2017). The World Bank. Retrieved October 10, 2017 from http://databank.worldbank.org/data/reports.aspx?source=world-development-indicators.

Zheng, P. (2009). A comparison of FDI determinants in China and India. Thunderbird International Business Review, 51(3), 263-279. doi: https://doi.org/10.1002/tie.20264 